\title{
EVOLUTION OF THE CONSOLIDATED GENERAL BUDGET AND BUDGET DEFICIT BETWEEN 2012-2016 IN ROMANIA
}

\author{
Alin Teodor HUSERAŞ \\ "Nicolae Bălcescu" Land Forces Academy, Sibiu, Romania \\ huseras.alin@gmail.com
}

\begin{abstract}
This article provides a synthetic and easily understandable image of important financial characteristics of the Romanian public system to any person interested in the issue. It draws in general lines the etymology, legal and economic relevance of the budget, as well as the budget system structure and its development under the laws of public finances. It also presents the formation and use of budgetary flows, budgetary principles, consolidated general budget, economic and functional classification and surplus or deficit of budget. The current paper draws on the most known analysis indicators used in the literature. As a group, these analysis indicators convey the level (volume or size), the structure (the destination groups, subgroups, categories) and dynamics (the evolution in time) of budget and can be applied to both income and expenditure budgets. The paper's objectives are to monitorize the evolution of the consolidated general budget and to analyse the employment deficit in the permissible limits (3\%) in the reference period of the study (2012-2016).
\end{abstract}

Keywords: Budget, financial system, financial flows, revenue and public expenditure, deficit / surplus

\section{Introduction}

The aim of the urrent research papaer is to present an analysis in terms of level, structure and dynamics of the general consolidated budget for 2012-2016. Current methods of analysis were used to determine and obtain budget economic indicators specific for this type of analysis.

The data used was collected from annual budgetary laws, from the state budget, from the general consolidated budget, and from the Government ordinances amending budget, specific to each year of this period. There were also used data published on the website of the Ministry of Finance (http://www.mfinante.gov.ro), data published by the National Statistics Institute (http://statistici.insse.ro), and data published by the EUROSTAT (http://ec.europa.eu/eurostat).
2. General approach to the Romanian financial system and state budget characteristics

What is budget? Everywhere in our daily lives we frequently hear this term, either as a singular term or in phrases such as: personal budget, family budget, institution budget, state budget, budget system and so on. Etymologically, this term derives from the Latin "bulgo", which means "bag" or "leather bag filled with money".

Over time, many states have borrowed this term, adapted it to their vocabulary and used it later with an economical meaning. As a specialized term, it was firstly used in official documents at the beginning of the thirteenth century in England. In Romania, this term first appeared in 1831 in the Organic Law[1].

Romania's transition to a market economy forced the public sector to make 
adjustments and changes both in the concept of the budget and in its organization. The first change was from the unique state budget of the communist system to the national budgets[2], which consisted of three separate budgets, and then to the unitary system of budgets[3] which consisted of six separate budgets. Later on, Law 500/2002 introduced the concept of budgetary system, which now consists of 9 budgets that regulate public funds.

Law 500/2002 on public finances defines the budget as a document subject to adoption from a legal and economic point of view, through which the income and expenditure are provided and approved by Parliament every year.

Very important to note is the fact that the state budget, as an official document, highlights:

- maximum approved spending - with precise purposes and goals that cannot be misregarded. Infringement of these conditions of financial discipline represents funds embezzlement, waste and abuse;

- minimum limits approved for revenue that will be collected and then made at the disposal of state. However, exceeding them, under tax respecting, is not an act of budget indiscipline, thus returning huge tasks for the collection and control authorities to identify all sources of income and to collect the full amounts for the state without committing tax abuses.

The economic approach to budget refers to the macroeconomic relationship between public and private sector, regarding the level and evolution of Gross domestic product (GDP). The level of GDP and the extent to which it is distributed for the formation of gross capital and consumptione determines the level of the budgetary indicators.

The volume and structure of revenue and expenditure varies from state to state depending on the level of economic development of the country, social and political conditions and international situation.

In Romania, the society need of resources and the possibilities of covering them are reflected in the consolidated general budget. Law 500/2002 on public finances states that the management of public financial resources is achieved through a budget system that includes the following budgets[4]:

- state budget;

- state social insurance budget;

- special funds budget;

- state Treasury budget;

- autonomous public institutions budget;

- budget of the public institutions that are fully or partially funded by state budget;

- budget of public institutions funded from their own revenues;

- budget funds from external loans contracted or guaranteed by the State;

- external grants budget.

The consolidated general budget is a general image of all the budgets of the budgetary system (aggregated, consolidated and adjusted), plus internal or external loans and minus any transfers between budgets and repayment of capital[5]. Two characteristics result from this description:

- budgets are aggregated by the fact that they highlight both values recorded as income and values recorded as costs;

- budgets are consolidated by eliminating transfer between budgets in order to avoid double entry of these amounts and by considering the real public financial effort.

Transfers between budgets represent transfers from one public budget to another. Budget adjustment involves financial operations of loan repayment with / without interest and recognition of exchange differences

\subsection{The system of public revenue}

Budget revenues are recorded and approved in the budget based on their sources and are divided into chapters and subchapters, grouped by their nature, according to the 
budget classification approved by the Minister of Public Finance.

The budgetary incomes come from:

- compulsory levies

- treasury resources

- resources from public loans

- currency issue
This revenue is constituted according to the law, on account of direct taxes (profit, income), indirect taxes contributions (the VAT, excise duties, customs duties) and non-tax revenues collected from individuals and companies, payments from public institutions, as well as other revenues annually approved by budget law.

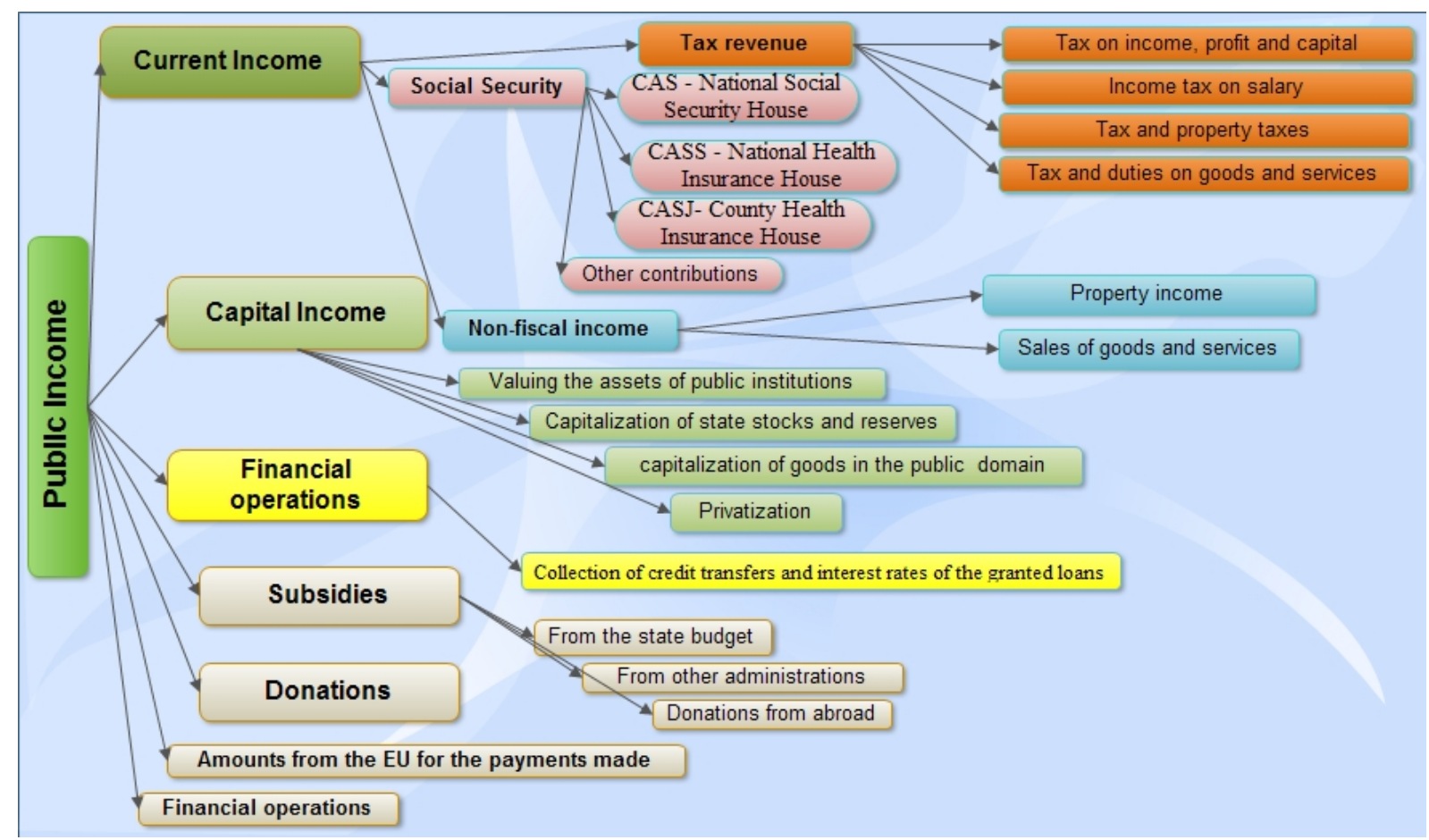

Figure nr1-The classification of public revenue accrding to the budget classification. Source: Own proccessing based on budget classification.

\subsection{The system of public expenditure}

Sizing of budget expenditures and their distribution by destination, category of expenditure and the beneficiaries are made in accordance with the objectives and priorities set by public authorities by means of the annual budget law. Through this law combined with amending laws, the budget appropriations are approved as maximum limit of expenses that can be incurred and made, according to functional classification and economic classification.

The functional classification is a synthetic organization, whose first stage of organization is ,the party", which groups expenses according to the purpose regarding different types of state shares and their proper functions. In each chapter of budgetary expenditures, the following main categories of expenditure are provided and approved by the the annual budget law:

- current expenditure, carried out on:

- Staff expenditure;

- material and services expenses;

- grants;

- reserves;

- transfers.

- capital expenditures

- loan repayments, interest payments and fees on loans.

Subsections and paragraphs gradually detail the purpose of the funds depending on units 
and shares.

Economic classification sort expenditures by title, articles and paragraphs, according to their nature and economic effect. This is a general and consistent classification throughout the public sector. It sits at the basis of organizing the synthetic and analytical records in every public institution.

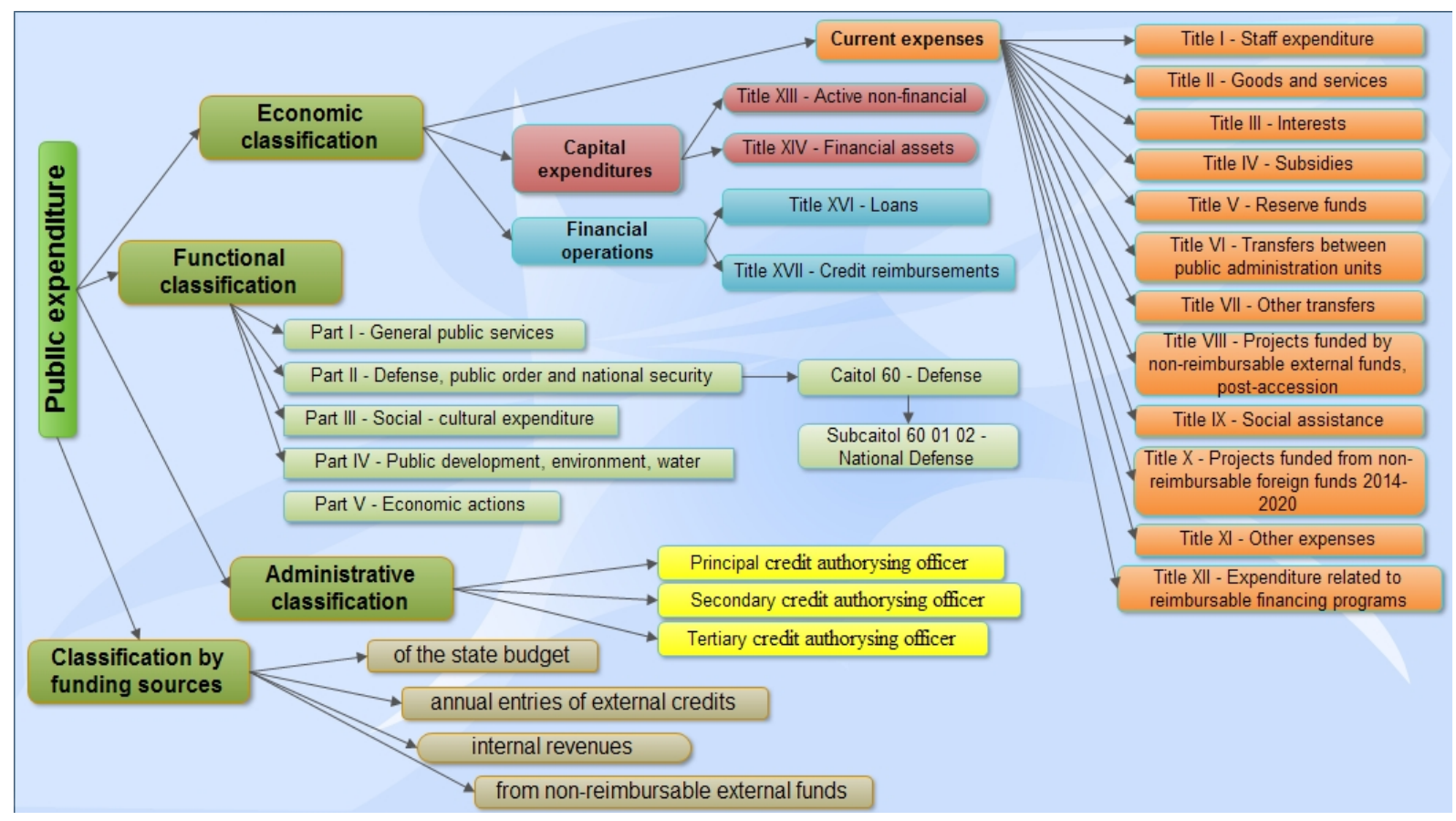

Figure $n r 2$ - The classification of public expenditures according to the functional and economical classification. Source: Own proccessing based on budget classification.

The budget deficit is an indicator that measures the budgetary expenditure (resources used by the government) that exceed income (resources from other institutional sectors) in a fiscal year budget.

Romania, as an EU country, agreed and ratified[6] provisions mentioned in Article 126 of the Treaty on European Union, through which the rules of procedure regarding the excessive deficit procedure under "Protocol (no. 12) on the excessive deficit procedure"[7] were established. European System of Integrated Economic Accounts defines budget deficit as net borrowing. The reference rates referred to in Article 126 are established as follows:

- $3 \%$ for the rate of planned or actual government deficit to gross domestic product at market prices;

- $60 \%$ for the rate of government debt to gross domestic product at market prices.

In Romania, due to fiscal relaxation measures initiated in 2015, which consisted of salary increases and higher social benefits, the budget deficit (cash, ESA and structural) has recorded a sharp increase since 2015. Noteworthy here are the main directions of action undertaken by the Macroeconomic Situation Report 2017[8] where it is intended that the amount allocated for investment to reach $6.8 \%$ of GDP, which would mean to follow the golden rule of public finance - 'investment levels to be higher than the deficit target". Budget deficit target in 2017 is estimated at $2.96 \%$ of GDP according to the Report on the macroeconomic situation in 2016 and its projection for the years 2017-2019.

The budget surplus is an indicator that measures the budget revenues exceeding budget expenses in a budget year. 


\section{The research methodology}

The research methodology used to achieve the objectives of the study relies on a mixture of methods essentially based on qualitative research. Documentary analysis (official documents, legislation, strategies, projects, etc.) which is the basis of a qualitative scientific approach, allows operation of a rich range of information regarding Romanian financial and budgetary systems. The first objective of the research consists of monitoring the evolution of general consolidated budget in the reference period of the study.

The second goal is to analyse the compliance of deficit to the maximum extent permitted by Protocol No. 12 on the excessive deficit procedure annexed to the Treaty on the Functioning of the EU in 2012-2016

\subsection{Analysis indicators of the revenue and expenditure budgets}

The analysis of public revenue and expenditure offers an accurate picture of any state's financial policy as well as a comprehensive economic and financial situation linked to accomplishing and using budget flows, in an analysed period of time or at any given time. These analyses can play an important role in the governmental management of any state. Plans and strategies undertaken can be verified based on the results, the objectives and expected levels in projects. Furthermore, this analysis can also serve to conduct comparison studies about states pertaining to an alliance or union regarding the fulfillment of the levels and responsibilities required.

In this article were used the best known analysis indicators used in scientific literature.

As a group, these analysis indicators reflect: the level (volume and size), the structure (the destination of the groups, subgroups, categories) and dynamics (the evolution over time).

\subsection{Results and interpretations - GDP evolution 2012-2016}

Regarding the evolution of GDP between 2012-2016 in Romania, we can say that it had not seen any decrease, but had recorded steady growth throughout the period.

Between the maximum limits of the reference period, GDP increased by $26.89 \%$, from 595.4 billion lei in 2012 , to 755.56 billion lei in 2016. The data regarding the development can be easily seen and interpreted in the table below.

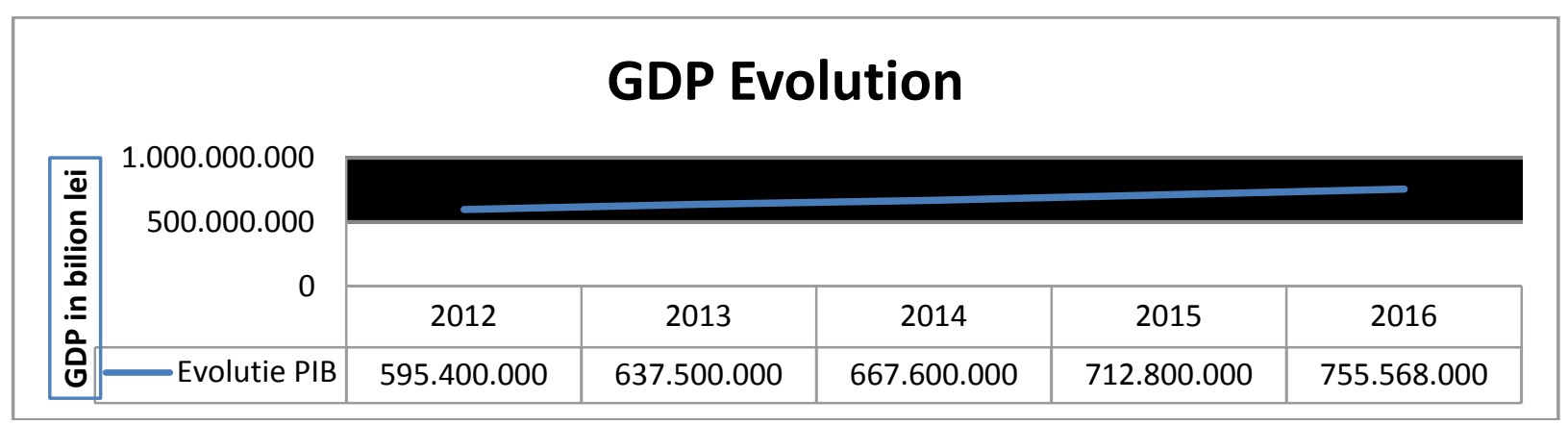

Graph nr 1 - GDP evolution 2012-2016.

Source: own processing based on the GDP published on www.ins.ro

Macroeconomic indicators analysis of budgetary construction

\begin{tabular}{|c|c|c|c|c|c|c|}
\hline \multicolumn{7}{|c|}{ MAIN MACROECONOMIC INDICATORS OF THE BUDGET - SUMMARY } \\
\hline Indicators/Years & Um & 2012 & 2013 & 2014 & 2015 & 2016 \\
\hline GDP & Bilion lei & $595.367,3$ & $637.456,0$ & $667.577,4$ & $712.832,3$ & $755.568,1$ \\
\hline Economical growth & $\%$ & 0,6 & 3,5 & 3 & 3,8 & 4,1 \\
\hline The average annual inflation & $\%$ & 3,3 & 4 & 1,1 & $-0,6$ & $-1,5$ \\
\hline Average exchange rate & lei/euro & 4,456 & 4,419 & 4,4446 & 4,445 & 4,4908 \\
\hline $\begin{array}{l}\text { Income of } \\
\text { General Government Budget }\end{array}$ & Bilion lei & $193.148,2$ & $200.374,3$ & $214.314,9$ & $233.795,2$ & $223.721,9$ \\
\hline Rate of total revenues in GDP & $\%$ & 32,4 & 31,4 & 32,1 & 32,8 & 29,5 \\
\hline $\begin{array}{l}\text { Expenditure of } \\
\text { General Government Budget }\end{array}$ & Bilion lei & $207.922,2$ & $216.168,3$ & $225.808,1$ & $243.426,0$ & $242.016,3$ \\
\hline $\begin{array}{l}\text { Rate of total expenditure in } \\
\text { GDP }\end{array}$ & $\%$ & 34,9 & 33,9 & 33,8 & 34,1 & 31,9 \\
\hline
\end{tabular}




\begin{tabular}{|l|c|r|r|r|r|r|}
\hline Deficit & Bilion lei & $-14.773,9$ & $-15.794,0$ & $-11.493,2$ & $-9.630,7$ & $-18.294,3$ \\
\hline Deficit - Rate in GDP & $\%$ & $-2,5$ & $-2,5$ & $-1,7$ & $-1,4$ & $-2,4$ \\
\hline Unemployed (total persons) & & 493.775 & 512.333 & 478.338 & 436.242 & 418.237 \\
\hline Average net monthly earnings & lei & 1.547 & 1.622 & 1.706 & 1.848 & 2.088 \\
\hline
\end{tabular}

Graph nr 2 - Macroeconomic indicators analysis of budgetary construction 2012-2016.

Source: own processing based on the published on www.ins.ro

\section{Consolidated budget structure}

The analysis of budget execution in the reference period of the study (January 1, 2012 - December 31st 2016) was made based on the data regarding the execution of consolidated general budget published on http://www.mfinante.ro. During the reference period of the study, overall budget revenues have ranged from $29.5 \%$ to $32.79 \%$ of GDP. The highest level of revenues was recorded in 2015 , but due to fiscal relaxation measures initiated that year, 2016 revenues have decreased by $4.3 \%$ in comparison with the previous year, and a decrease of 3.29 percentage points of GDP was recorded, which brought GDP to its lowest level from the reference period.

Consolidated general government expenditures have ranged from $31.9 \%$ to $34.92 \%$ of GDP. The highest level of public expenditure in the reference period was recorded in 2012, it dropped by 0,1 GDP pp in 2013, 0.9 pp in 2014. In 2015 it rose with 0,28 GDP pp. In 2016 their level was of 243.4 billion lei, representing $31.9 \%$ of GDP and $96.9 \%$ degree of achievement of required level.

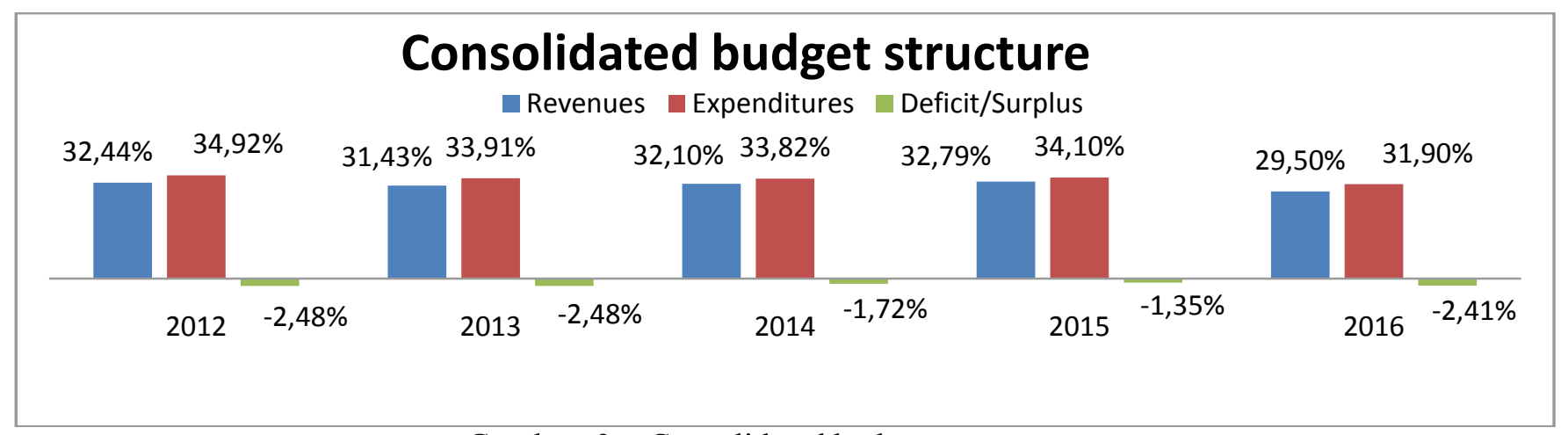

Graph nr 3 - Consolidated budget structure.

Source: own processing based on 2012-2016 consolidated budgets published on Ministry of Public Finance

Consolidated general government revenues, in 2016, came to a total of 223,7 billion lei, which represented $29,5 \%$ of GDP a $95,1 \%$ degree of achievement of required level. In comparison with the previous year, in 2015 Consolidated general government revenues registered a nominal decrease of 10 billion lei in relative value of $4,5 \%$, and as a percentage in GDP, they have decreased with 3,3 pp, from $32,8 \%$ in 2015 to $29,5 \%$, in 2016 .

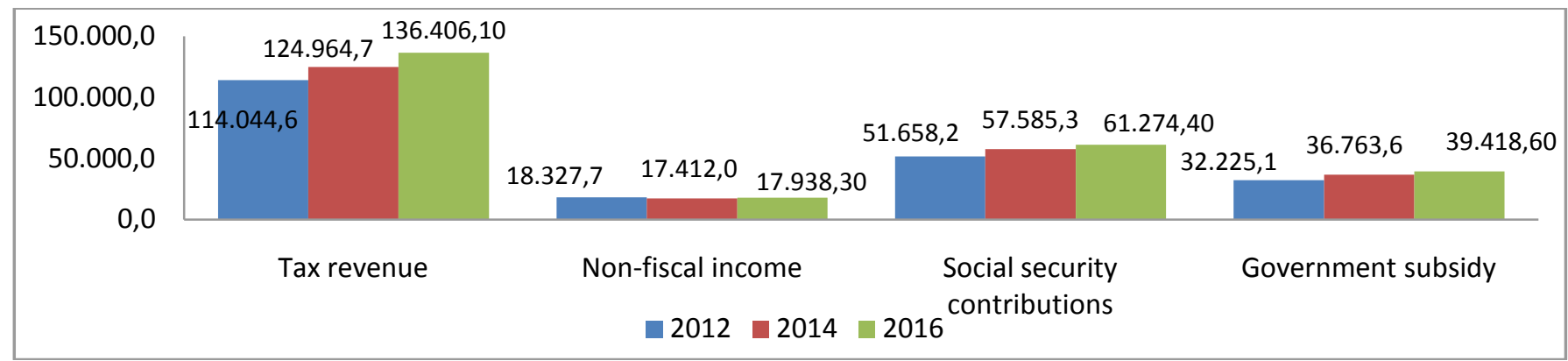

Graph nr 4 - The structure of income budget - billion lei.

Source: own processing based on the GDP 2012-2016 published on Ministry of Public

Finance 
Consolidated general government expenditures in 2016 totaled 242 billion, which represents $31.9 \%$ of GDP and a degree of achievement of the level required by $96.9 \%$. Current expenditure (expenditure on personnel, goods and services, interest, subsidies), transfers, funds projects of EU, Social assistance Capital expenditures, Other expenditures in 2016 represent $29.51 \%, 14.28 \%, 0.89 \%$ $, 2.51 \%, 0.65 \%$ of total expenditures.

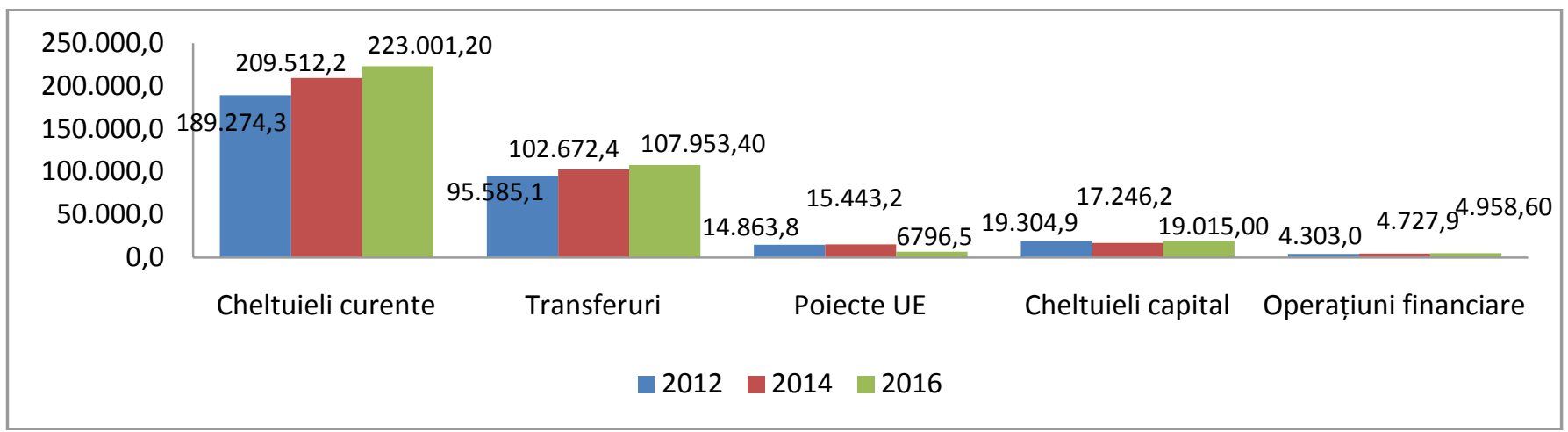

Graph nr 5 - The structure of exediture in budget (Current expenditure, transfers, EU Funded Projects, Capital Expenditure, Financial Operations) - bilion lei.

Source: own processing based on the GDP 2012-2016 published on Ministry of Public Finance

In Romania, the structure of budget deficit in comparison with the previous year, increased as a percentage of GDP by 1.1

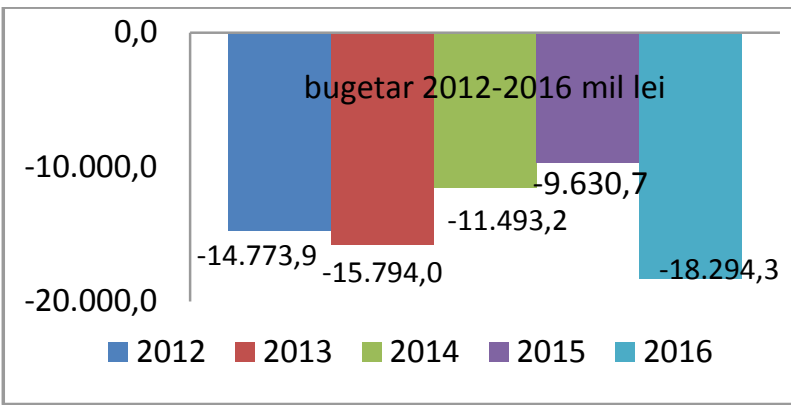

Graph nr. 6 Source: own processing based on the GDP 2012-2016 published on Ministry of Public Finance percentage points from $1.4 \%$ in 2015 to $2.5 \%$ in 2016. The differences between 2015 and 2016 is of 8.66 billion lei

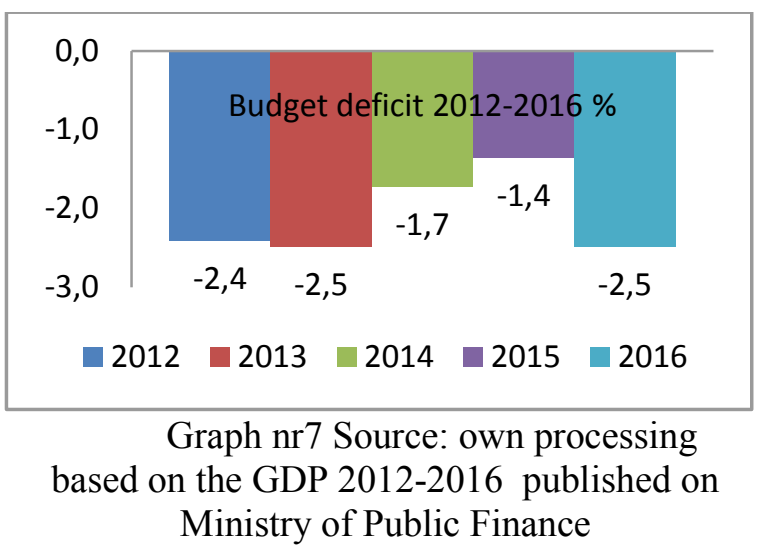

which are described the economic relations as they are formed throughout the process of gross domestic product distribution.

It is important to establish realistic goals and achievable indicators in the process of budgeting. This fact can be seen in the performance reports, by comparing the actual data with the provided budget.

Due to the fact that budgets present important guidelines for government 
actions, the public finances will always be a field open to research activities, such as the development of new theoretical analysis and case studies through which budgetary activity can be performed and continuously improved.

\section{Bibliographical references}

Law 388/2007 - State Budget Law, 2008

Law 18/2009 - State Budget Law, 2009

Law 11/2010 - State Budget Law, 2010

Law 286/2010 - State Budget Law, 2011

Law 293/2011- State Budget Law, 2012

Law 5/2013 - State Budget Law, 2013

Law 356/2013 - State Budget Law, 2014

Law 186/2014 - State Budget Law, 2015
Law 339/2015- State Budget Law, 2016

Law no. 69 / 2010 fiscal-budgetary responsibility

Law nr. 500 / 2002 on public finance

Law $10 / 1991$ on public finance

Law $72 / 1996$ on public finance

Tulai C - Public finance and taxation, ed.

Casa Cărții de Știință, Cluj Napoca 2003

Georgescu M. A. - Administration of public finances and budget, ed. Pro Universitaria 2011

Ștefura G. Public finances and taxation, ediţia a II-a, ed. Expert, București 2007

National Institute of Statistics

\section{References}

[1] Georgescu M. A. - Administration of public finances and budget, ed. Pro Universitaria 2011, pag. 182

[2] Art. 10 Law 10/1991 on public finance

[3] Law 72/1996 on public finance

[4] Paragraph 2. Art 1. Cap.1 Law nr. 500 from July, 11 $1^{\text {th }}, 2002$ on public finances

[5] Paragraph 2 Art 3 Law no. 69 of 16 April 2010 fiscal-budgetary responsibility

[6] So as to respect the reference values for budget deficit and public duty, the benchmarks imposed in Protocol 12, through modifications of Law no. 69/2010 of fiscal budgetary responsibilities, article 7 and $7 \mathrm{nr}$ 69/2010, were taken into the national legislation.

[7] Protocol no. 12 regarding the procedure that applies to excessive deficits, appendix to the consolidated version of the treaty regarding the functioning of EU and the Fundamental Rights Book of EU. Romania ratified the Treaty of Lisbon through which is modified the Treaty regarding EU and the Treaty of establishing the European community by Law no. $13 / 2008$.

[8] Report regarding the macroeconomic situation in 2017 and its projection in 2018-2020, emmited by the Romanian Government on 23.01.2017 